\title{
A Note of Names and Censors
}

\section{Frederic G. Cassidy}

\begin{abstract}
Divagations of an old Onomastician on this and that, with a kindly thought for Len Ashley.
\end{abstract}

The basic difference between names and words is that names confer particular being or individual identity while words refer generally. In language learning, everything begins as a name. For a child first grasping the system, there are only names, bed, finger, doll: there is only one of each in its experience. The move from name to word comes with the discovery that there are other similar things. The child may cling to the original, familiar object: my bed, my finger, my doll, or may discover the general naming process - the use of the capital letter, so to speak - and name the doll Dolly. In English, French, German it may discover the articles: the le, la, der, die, das in their particularizing function. The generalizing process is complete with discovery of the indefinite article: a bed, finger, doll, fully depersonalized, merely one member of a class or type - no longer a name: merely a word.

The naming process as one that confers conceptual being has never been better described than by Shakespeare's picture of poetic creation. (Note that in Greek poet means 'creator'):

\footnotetext{
The poet's eye in a fine frenzy rolling doth glance from heaven to earth, from earth to heaven, and as imagination bodies forth the forms of things unknown, the poet's pen turns them to shapes, and gives to airy nothing a local habitation and a name.
} 
Nothing exists concretely in human thought (no paradox!) until it exists as a word, name gone general, a conventionalized set of sounds, oral or otherwise recorded.

The process of name-giving happens within a social context; therefore judgment, overt or covert, is involved. In this way Solomon, the name of a specific, historic king, becomes a word, evoking the figure of a wise judge: "a solomon is come to judgment" in Shylock's words; and, similarly, a shylock, with a small $s$, an extortionate money-lender. In the course of this conversion, both names lose their capital letters - a printing convention that recognizes the difference between name and word.

Words made from names run the whole gamut of human values, from the honorific to the condemnatory. The first, recognizing a valuable contribution, is commonly used in the sciences for the names of units: watt, ampere, curie, marconi, ohm, with the interesting reversal of ohm to mho for its reciprocal of conductance. Other people, real or fictional, may survive through their names because of a single act or episode or characteristic attributed to them: a scrooge, a jezebel, a cassandra, a malaprop. And the word need not be a noun by simple transference: it may go on to be a verb: to lynch, to hector, to boycott. The namebearer may become totally forgotten except for the feature or act or episode that survives in the word, as Hamlet was well aware while he watched the players feigning sorrow: "What's he to Hecuba or Hecuba to him, that he should weep for her?" Hecuba has become no more to the player than a signal to begin shedding tears.

By social convention, usually religious, a special class of names develops - holy or sacred or tabu names, with rules about their proper use. When a name is so sanctioned, its use becomes restricted. It may be used rightly on only some occasions, serious ones. It must not be taken in vain. There is great danger in swearing, cursing, using imprecations: it is a challenge to power, an invitation to punishment. "The Lord shall not hold him guiltless that taketh his name in vain." So come into existence the names of avoidance: $E l$, as if one might gesture cautiously rather than pronounce the forbidden name: Him said in an undertone, with eyes glancing askance. To pronounce the names of the Mighty 


\section{Names 41.4 (December 1993)}

may be taken as invocation and one may get more than one bargained for. Speak of the Devil and he may put in an uncomfortable appearance. This is the danger of a name. To say that a man is a bastard may be a simple fact. To call him "bastard" is a kind of naming that may have nothing to do with fact. Any word for something nasty, physically or morally, can be used as an insulting name: words for the excrements are frequently used for this purpose.

Since individuals are constantly seeking areas of freedom or undiscipline that may work against their fellows, society feels the need to set limits to the public expression of certain words and names. In ancient Rome the officer assigned to this task was a censor. He had to count people (censere 'to take the census') but also, as special assistant to a judge, to execute matters of public record and material value. He also became an inspector of public morals and conduct. Thus he had to decide what was good for society and to ban what was not. One can see that the power of a censor could be considerable. People with ideas, especially unconventional ones, could easily be considered dangerous. Tolerance has varied over the ages. With dictatorial governments it has fluctuated, sometimes becoming quite arbitrary. Caligula, criticized by a writer, burned him alive; Domitian put to death a historian who had referred to him slightingly. Egregiously he also crucified the secretaries, as if by simply writing they shared the guilt.

As Justice Oliver Wendell Holmes put it, "Every idea is an incitement." And ideas are expressed in words and through names. Bookburning and other physical forms of censorship may satisfy the literal-minded. Indices of prohibited books, general restraints on the press, the theater, television, are nominally preventative, to nip the idea in the bud. Except in the most efficient autocracies, the word and name leak through. But a secondary form of censorship, by disinformation or misinformation, is exercised - perhaps justified in times of war, declared or not, when it becomes a weapon. Secrecy is a temptation to certain minds.

Critics whose names have become synonymous with censorship are a special breed: their motives are moral: for better or 
worse they seek to benefit society, even against its will. In 1818 Thomas Bowdler published in England in ten volumes the "Family Shakespeare," an edition in which he omitted or modified parts "which cannot with propriety be read aloud in a family." His name survives as a noun, but especially as a verb to bowdlerize, meaning to remove from a text, or to alter, material considered indecent or indelicate. Though Bowdler's work preceded Victoria's reign, it shares the redolence of that age. An American of the following generation, Anthony Comstock, fought valiantly as Secretary of the Society for the Suppression of Vice (New York), making spectacular raids on publishers and vendors of books he considered indecent. Through the Post Office department he censored dissemination of such publications, earning the nameword Comstockery for his books, Traps for the Young (1883) and Morals vs Art (1887). In both these cases we can see the censor censored, the word derisive and the word condemnatory.

A special type of name related to words is the nickname. Etymologically this is simply an "eke-name," an added name, and the process of nicknaming is ultimately responsible for surnames. (In French, surnom still means "nickname.") When too many men in a community are named John, one has to add on a distinguishing word: John Baker, John Brown, John Atwell. But many - or still further - nicknames may be given to express all kinds of qualities, opinions, actions, social judgments, which may have the effect of censorship. Such names as Coward, Meech, Fitzroy, surely began as expressions of social derogation, though they might be forgotten or lived down by later generations.

I leave aside the psychological meaning of censor, which my dictionary defines as "a hypothetical psychic agency that represses unacceptable notions before they reach consciousness." This operates within the fastness of our skull, and even when a notion, a velleity reaches consciousness, subliminally present but unexpressed, it takes the form of words or names. These, then, may have to be consciously censored again, kept unspoken or unwritten, to avoid the power of the social censor, public censorship.

A concluding anecdotic note may perhaps escape censorship. In the north of England, where stressed $u$ is schwa in such words 


\section{Names 41.4 (December 1993)}

as Durham, a visiting lecturer from Germany, a Herr Professor Doktor Fuchs, had to be introduced by a Scottish professor, who found himself in a quandary. He consulted a colleague: What am I to do? I can't decently call him 'Fooks'?" His solution, when the time came for the introduction, was to introduce the speaker as "Professor Fucks." That, in that part of the world, he could properly say.

The clash between names and ordinary words produces a special form of discomfort, especially at naming-time, when new parents can show a notable lack of sensitivity labeling their children in ways that they can never live down. I went to high school with the children of a physician, Dr. Branch, the girl named Olive, the boy named Forrest. Did those names represent some sense of cuteness, a type of vapid humor? Did those parents not have the imagination to see that they were saddling their children with a weak witticism that they must endure the rest of their lives? A bit of foresighted sensitivity - and a bit of censorship - might have been appropriate. A personal name is a lifelong label, for better or worse. In France when a newborn is officially registered, oddities are not accepted. Only names on the established calendar can be given. No babies can be endowed with such monikers as Goolan, Marjil, or Blunt. Here, perhaps, the state's intrusion on personal freedom may have some defense. 